Research Article

\title{
Frequency and spectrum of hemoglobinopathy mutations in a Uruguayan pediatric population
}

Julio Da Luz ${ }^{1}$, Amalia Ávila ${ }^{1}$, Sandra Icasuriaga $^{2}$, María Gongóra $^{3}$, Luis Castillo ${ }^{3}$, Alejandra Serrón ${ }^{1}$, Elza Miyuki Kimura ${ }^{4}$, Fernando Ferreira Costa $^{5}$, Mónica Sans ${ }^{6}$ and Maria de Fátima Sonati ${ }^{4}$

${ }^{1}$ Departamento de Genética, Facultad de Medicina, Universidad de la República, Montevideo, Uruguay.

${ }^{2}$ Departamento de Laboratorio Clínico, Centro Hospitalario Pereira Rosell, Montevideo, Uruguay.

${ }^{3}$ Servicio de Hemato-Oncología Pediátrica, Centro Hospitalario Pereira Rosell, Montevideo, Uruguay.

${ }^{4}$ Departamento de Patologia Clínica, Faculdade de Ciências Médicas, Universidade Estadual de Campinas, Campinas, SP, Brazil.

${ }^{5}$ Hemocentro, Faculdade de Ciências Médicas, Universidad Estadual de Campinas, Campinas, SP, Brazil.

${ }^{6}$ Departmento de Antropología Biológica, Facultad de Humanidades y Ciencias de la Educación,

Universidad de la República, Montevideo,Uruguay.

\begin{abstract}
Hemoglobinopathies are the most common recessive diseases worldwide but their prevalence in Uruguay has not been investigated. In this study, 397 unrelated outpatient children from the Pereira Rosell Hospital Center (CHPR), as well as 31 selected patients with microcytic anemia and $28 \beta$-thalassemia carriers were analyzed for hemoglobinopathies by using biochemical and molecular biology methods. Parametric and non-parametric methods were used to compare the hematological indices between groups of genotypes. Of the 397 patients in the first group, approximately $1 \%(0.76 \% \mathrm{HbS}$ and $0.25 \% \beta$-thalassemia) had a mutation in the $\mathrm{HBB}$ gene and $3.3 \%$ had $\alpha$-thalassemia. These mutations had a heterogeneous distribution that varied according to individual ancestry. $\mathrm{HbS}$ was found exclusively in individuals with declared African ancestry and had a carrier frequency of $2.2 \%$. The frequency of $\alpha$-thalassemia carriers in outpatients of European and African ancestry was $1.2 \%$ and $6.5 \%$, respectively. In contrast, the frequency of $\alpha$-thalassemia carriers in patients with microcytic anemia was $25.8 \%$, significantly higher $(p<0.01)$ than that observed in the sample as a whole and in Afro-descendants and Euro-descendants. Significant differences were observed in the hematological parameters between individuals with thalassemia genotypes and those with a normal genotype. These results indicate that hemoglobinopathies are a relevant health problem in Uruguay.
\end{abstract}

Keywords: alpha-globin, beta-globin, hemoglobinopathies, Uruguayan population.

Received: October 18, 2012; Accepted: April 12, 2013.

\section{Introduction}

Hemoglobinopathies are the most common recessive diseases worldwide, possibly because of a selective advantage in the presence of malaria tropica (Steinberg et al., 2001). Hemoglobinopathies form two main categories: those resulting from structural hemoglobin $(\mathrm{Hb})$ variants and thalassemias. Among the structural $\mathrm{Hb}$ variants, the most frequent are $\mathrm{HbS}$ and $\mathrm{HbC}$ that are present in high frequencies in sub-Saharan Africa; $\mathrm{HbS}$ is also present in high frequencies in India and Saudi Arabia (Allison 1956; Stein-

Send correspondence to Maria de Fatima Sonati. Departamento de Patologia Clínica, Faculdade de Ciências Médicas, Universidade Estadual de Campinas, Rua Tessália Vieira de Camargo 126, Cidade Universitária Zeferino Vaz, 13083-887 Campinas, SP, Brazil. E-mail: sonati@fcm.unicamp.br. berg et al., 2001). Hemoglobinopathies resulting from these structural variants are an important health problem in the Americas, where they reflect the contribution of individuals of African descent.

Thalassemias are characterized by a decrease in or lack of synthesis of one or more globin chains resulting in a reduced rate of synthesis or absence of hemoglobin(s) (Weatherall and Clegg, 2001; Weatherall, 2004). $\alpha$-Thalassemias are caused by a reduction in $\left(\mathrm{a}^{+}\right)$or complete suppression of $\left(\alpha^{0}\right) \alpha$-globin chain synthesis, caused mainly by deletions of one $(-\alpha)$ or both (- -) HBA genes, although non-deletional $\alpha$-thalassemia caused by small deletions or point mutations contributes to the spectrum of $\alpha$-thalassemia mutations (Foglietta et al., 1996; Steinberg et al., 2001). 
Thalassemias occur in high frequencies in tropical and sub-tropical regions of Africa, the Mediterranean basin and Southeast Asia, where malaria is or has been endemic. However, as a result of population migration and the African slave trade these diseases have spread throughout the world and are now an important health problem in the Americas (Weatherall and Clegg, 2001). A frequent determinant of $\alpha$-thalassemia is a $3.7 \mathrm{~kb}$ deletion $\left(-\alpha^{3.7}\right.$ deletion) that affects the two $H B A$ genes and results in a unique hybrid gene (HBA2-HBA1). This deletion is common in all areas with a high prevalence of thalassemia but reaches its highest frequencies in Africa and in some populations in Asia. In many cases, the hematological alterations observed in individuals with this deletion are very mild or silent.

Another frequent determinant of $\alpha$-thalassemia is the $4.2 \mathrm{~kb}$ deletion ( $-\alpha^{4.2}$ deletion) that eliminates the $H B A 2$ globin gene completely. This deletion is found most frequently in Asian populations but also occurs in Mediterranean regions in lower frequencies. In the Mediterranean region, the -- ${ }^{\mathrm{MED}}$ and $-(\alpha)^{20.5}$ deletions are the most frequent causes of $\alpha^{0}$-thalassemias, while the deletion of a pentanucleotide (TGAGG) located at the $5^{\prime}$ end of the IVS-I of the $H B A 2$ gene (denominated $\alpha^{\mathrm{HpHI}} \alpha$ ) and a single point mutation at the initiation codon (ATG-ACG) of the $H B A 2$ gene, as well as a single point mutation (ATG-GTG) in the $H B A 1$ gene, are the most common non-deletional determinants of $\alpha$-thalassemias in this region (Higgs et al., 1989; Foglietta et al., 1996; Kattamis et al., 1996; Steinberg et al., 2001).

$\beta$-Thalassemias, which are caused by $>190$ mutations, are frequent in the Mediterranean region and southeastern Asia. Although most of these mutations are single base substitutions or small deletions or insertions within or flanking the $H B B$ gene, large deletions or insertions have also be observed. Generally, in any given population, there will be a group of a few common mutations and a large number of rare ones (Huisman et al., 1996; Hardison et al., 1998).

The Uruguayan population originated mainly from European populations (Spanish, Italian and others), subSaharan African populations and native American populations but, unlike other South American countries, there are no isolated Afro-Uruguayan or native American communities. The contribution of these parental populations to the Uruguayan genetic pool is geographically heterogeneous and non-negligible, as reflected in genetic data showing contributions of $92 \%, 7 \%$ and $1 \%$ from European, African and Native Americans, respectively, in Montevideo, southern Uruguay; the corresponding figures for Tacuarembó, in northeastern Uruguay are 65\%,15\% and 20\% (Sans et al., 1997). According to a Continuous Household Survey based on self-identification (I.N.E., 1997), the Uruguayan population is classified as $93.3 \%$ European, $5.9 \%$ black or mu- latto, $0.4 \%$ native and $0.4 \%$ Asian. Recent data based on self-declared ancestry indicate that $87.4 \%$ of the population has exclusively European ancestry, 9.1\% African ancestry, $2.9 \%$ native American ancestry and $0.6 \%$ other ancestries (Buchelli and Cabella, 2006).

In view of the ethnic origin of Uruguayan populations, it is possible that hemoglobinopathies may occur in high frequencies. An earlier study in Uruguay showed that $10 \%$ of individuals with African-ancestry were $\mathrm{HbS} / \mathrm{HbA}$ carriers, a frequency similar to that observed in other countries in the Americas (Da Luz et al., 2006). However, apart from the foregoing study, there are no data on the frequency and spectrum of mutations that cause hemoglobinopathies in the Uruguayan population. Moreover, there are no data on $\beta$-thalassemias although most of the Uruguayan population originated in the Mediterranean region. Approximately $19 \%$ of preschool Uruguayan children have anemia (WHO, 2008), but the causes of the disease are not always clear. The aim of this study was to contribute to our understanding of the epidemiology of hemoglobinopathies in the Uruguayan population by investigating the frequencies of structural and mutation-associated thalassemias and their impact on the prevalence of anemia in the country. This is the first study of its kind for this country.

\section{Subjects and Methods}

The sample consisted of 428 unrelated children between 2 and 15 years of age were analyzed, including a main sample of 397 outpatients randomly recruited at the Pereira Rosell Hospital Centre (CHPR) in 2006 who presented health problems unrelated to hemoglobinopathies. The children were grouped as being of either European (259) or African (138) descent based on their ancestors origin. To be classified as Afro-descendants the children had to have at least one grandparent of African origin. When their ancestry was unknown, children were classified according to their parents' self-identification, as reported in the 1996-1997 Continuous Household Survey (I.N.E., 1997). The remaining 31 blood samples belonged to children referred to the Pediatric Hematology and Oncology Service (PHOS) at the CHPR for investigation of microcytosis and hypochromia without iron deficiency and with normal levels of $\mathrm{HbA} 2$. The study was approved by the CHPR Ethics Committee and the children's parents gave written informed consent for them to participate in the study.

Red blood cell (RBC) indices were determined electronically with an automated cell counter (Cell Dyn 3700, USA). The presence of $\beta$-thalassemias and the most common $\mathrm{Hb}$ structural mutations ( $\mathrm{HbS}, \mathrm{HbC}$ ) was investigated by electrophoresis on cellulose acetate strips at $\mathrm{pH} 8.5$

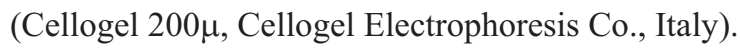

Genomic DNA was obtained from peripheral blood leukocytes by saline extraction (Miller et al., 1988). Patients were screened for deletional and non-deletional $\alpha$ - 
thalassemias using polymerase chain reaction (PCR)-based methods. The most common $\alpha$-globin deletions $\left(-\alpha^{3.7},-\alpha^{4.2}\right.$, - _ ${ }^{\mathrm{SEA}},{ }_{-}{ }^{\mathrm{FIL}},{ }_{-}{ }^{\mathrm{MED}},-(\alpha)^{20.5}$ and - - $\left.{ }^{\mathrm{THAI}}\right)$ were identified by multiplex PCR while non-deletional forms were identified by restriction fragment length polymorphism (RFLP) from products amplified by PCR $\left(\alpha^{\mathrm{Hph}} \alpha, \alpha^{\mathrm{Ncol}} \alpha\right.$ and $\left.\alpha \alpha^{\mathrm{NcoI}}\right)$ (Hall et al., 1993; Tan et al., 2001). The $H B B$ gene was amplified and sequenced to confirm and identify $\beta$-globin mutations (Miranda et al., 1997). In samples with the $\mathrm{HbS}$ mutation, five polymorphic sites in the $\beta$-globin gene cluster were analyzed: 1) HincII 5 ' $\varepsilon, 2)$ HindIII $^{G} \gamma$, 3) HindIII ${ }^{A} \gamma$, 4) HincII 5 ' $\psi \beta$ and 5) HincII 3' $\psi \beta$. Fragments containing each of these sites were amplified by PCR using previously described primers and conditions (Sutton et al., 1989; Guerreiro et al., 1992). Haplotypes were constructed by assuming that the presence of two common haplotypes was more probable than the combination of one common and one rare haplotype or of two rare haplotypes (Kulozik et al., 1986; Long et al., 1990; Castro de Guerra et al., 1997; Vívenes De Lugo et al., 2003). The genotypic and allelic frequencies were estimated by gene counting. The former were compared between the groups using Fisher's exact test with the Arlequin software package v.2.000 (Schneider et al., 2000).

Hemoglobin values, mean corpuscular volume (MCV), mean corpuscular hemoglobin $(\mathrm{MCH})$ and $\mathrm{RBC}$ values were corrected for age and sex. The distribution of these values and the red blood cell distribution width (RDW) were compared among individuals with different genotypes in the main sample and among 28 carrier children previously diagnosed with $\beta$-thalassemia at the CHPR. Hemoblogin and RBC were compared by multivariate analysis of variance (MANOVA) followed by the Student-Newman-Keuls (SNK) test for pairwise multiple comparisons between groups. The Mann-Whitney test was used to compare MCV, MCH and RDW to account for non-normality. The tests were done using SPSS v.12.0 with $\mathrm{p}<0.05$ as the level of significance.

\section{Results}

We identified three $\mathrm{HbS}$ carriers $(\mathrm{HbS} / \mathrm{HbA})(0.75 \%)$ in the main, randomly recruited CHPR sample, all of whom had been classified as Afro-descendants. The frequency of the $\beta^{\mathrm{S}}$ mutation was $0.38 \%$ but increased to $1.1 \%$ for individuals of African origin (Table 1). In two individuals the $\mathrm{HbS}$ mutation was probably associated with the Bantu haplotype whereas the other was associated with the Benin haplotype.

Although only one sample (an individual of European ancestry) had increased $\mathrm{HbA} 2$, after sequencing the $H B B$ gene in 15 samples with an MCV of $<75 \mathrm{fL}$ and an RBC value $>5$ million $/ \mu \mathrm{L}$, the only $\beta$-thalassemia mutation found (the $\mathrm{b}^{0}$ codon 39 mutation $\mathrm{C}>\mathrm{T}$ ) was identified in this individual. Results for $\alpha$-thalassemias in the random sample are summarized in Table 2 . The only $\alpha$-thalassemia mutation observed in the sample was the $-\alpha^{3.7}$ mutation, which accounted for $3.3 \%$ of the mutations and was present in a heterozygous state $\left(-\alpha^{3.7} / \alpha \alpha: 3 \%\right)$ in 12 individuals and in a homozygous state $\left(-\alpha^{3.7} /-\alpha^{3.7}: 0.3 \%\right)$ in one. Of the 259 Euro-descendants, three $(1.2 \%)$ were heterozygous $\left(-\alpha^{3,7} / \alpha \alpha\right)$; ten of the 138 Afro-descendants $(7.2 \%)$ also had this mutation - nine $(6.5 \%)$ were heterozygous $\left(-\alpha^{3.7} / \alpha \alpha\right)$ and one $(0.7 \%)$ was homozygous $\left(-\alpha^{3.7} /-\alpha^{3.7}\right)$. Mycrocytosis was detected in 27 Afro-descendants and 28 Eurodescendants; nine $(33.3 \%)$ of the former and only one (3.6\%) of the latter had $\alpha$-thalassemia. The genotypic frequencies differed significantly between Afro- and Eurodescendants $(p<0.001)$, between individuals with or without microcytosis $(\mathrm{p}<0.001)$ and between Afro- and Eurodescendants with microcytosis $(\mathrm{p}=0.0047)$.

Of the 31 PHOS pediatric patients who presented with microcytosis and hypochromia, $10(32.3 \%)$ had $\alpha$-thalassemia: eight $(25.8 \%)$ were heterozygous for the $-\alpha^{3.7}$ deletion, one $(3.2 \%)$ was homozygous for the same deletion $\left(-\alpha^{3.7} /-\alpha^{3.7}\right)$ and one $(3.2 \%)$ was heterozygous $\left(\alpha \alpha /-\alpha^{20.5}\right)$, this being the first reported case of the $-\alpha^{20.5}$ deletion in Uruguay. These frequencies did not differ significantly from those observed in individuals with microcytosis in the random sample.

The RBC indices in individuals with $\alpha$-thalassemia genotypes, $\beta$-thalassemia trait and normal $\alpha$ - and $\beta$-globin genotypes are shown in Table 3. MANOVA revealed significant differences in the $\mathrm{Hb}$ values and $\mathrm{RBC}$ indices between the genotypes (Pillai's trace for comparison among

Table 1 - Frequency of HbS in the main sample and in Afro-descendants.

\begin{tabular}{|c|c|c|c|c|c|c|}
\hline & \multirow[b]{2}{*}{$\mathrm{N}$} & \multicolumn{3}{|c|}{ Genotypic frequencies } & \multicolumn{2}{|c|}{ Allelic frequencies } \\
\hline & & $\beta^{\mathrm{A}} /$ non $\beta^{\mathrm{S}}$ & $\beta^{\mathrm{A}} / \beta^{\mathrm{S}}$ & $\beta^{\mathrm{S}} / \beta^{\mathrm{S}}$ & $\beta^{\mathrm{A}}$ & $\beta^{\mathrm{S}}$ \\
\hline All ${ }^{1}$ & 397 & $394(99.24)$ & $3(0.76)$ & 0 & 0.9960 & 0.0038 \\
\hline Afro-descendants ${ }^{1}$ & 138 & $135(97.78)$ & $3(2.22)$ & 0 & 0.9890 & 0.0110 \\
\hline Afro-descendants ${ }^{2}$ & 40 & $36(90)$ & $4(10)$ & 0 & 0.9500 & 0.0500 \\
\hline $\mathrm{p}^{*}$ & \multicolumn{4}{|c|}{$0.0458 \pm 0.0018$} & & \\
\hline
\end{tabular}

${ }^{1}$ Present study, ${ }^{2}$ Da Luz et al. (2006). Percentage in parentheses. *Difference between the two groups of Afro-descendants. 
Table 2 - Frequency of $\alpha$-thalassemia in the main sample and in individuals grouped according to ancestry and the presence or absence of microcytosis.

\begin{tabular}{|c|c|c|c|c|c|c|c|}
\hline \multirow[b]{2}{*}{ Subjects } & \multicolumn{4}{|c|}{ Genotypic frequencies } & \multirow[t]{2}{*}{$\mathrm{N}$} & \multicolumn{2}{|c|}{ Allelic frequencies } \\
\hline & $\alpha \alpha / \alpha \alpha$ & $-\alpha^{3.7} / \alpha$ & $-\alpha^{3.7} /-\alpha^{3.7}$ & $-\alpha^{20.5} / \alpha \alpha$ & & $-\alpha^{3.7}$ & $\alpha \alpha$ \\
\hline All & $384(96.7)$ & $12(3.0)$ & $1(0.3)$ & & 397 & 0.018 & 0.982 \\
\hline Afro-descendants & $128(92.8)$ & $9(6.5)$ & $1(0.7)$ & & 138 & 0.040 & 0.960 \\
\hline Euro-descendants & $256(98.8)$ & $3(1.2)$ & & & 259 & 0.006 & 0.994 \\
\hline $\mathrm{p}$ & & $<0.001$ & & & & \multicolumn{2}{|c|}{$<0.01$} \\
\hline Microcytic & $45(81.8)$ & $9(16.4)$ & $1(1.8)$ & & 55 & 0.100 & 0.900 \\
\hline Non-microcytic & $339(99.1)$ & $3(0.9)$ & & & 342 & 0.004 & 0.996 \\
\hline $\mathrm{p}$ & & $<0.001$ & & & & \multicolumn{2}{|c|}{$<0.001$} \\
\hline Afro- and microcytic & $18(66.7)$ & $8(29.6)$ & $1(3.7)$ & & 27 & 0.815 & 0.185 \\
\hline Euro- and microcytic & $27(96.4)$ & $1(3.6)$ & & & 28 & 0.982 & 0.018 \\
\hline Selected patients & $21(67.8)$ & $8(25.8)$ & $1(3.22)$ & $1(3.22)$ & 31 & 0.823 & 0.161 \\
\hline $\mathrm{p}^{*}$ & & $<0.01$ & & & & \multicolumn{2}{|c|}{$<0.01$} \\
\hline
\end{tabular}

Percentages in parentheses. *: Compared with Afro- and Euro-descendants. N: Number of individuals.

Table 3 - Red blood cell indices in normal patients, in patients with $\alpha$-thalassemia genotypes and in $\beta$-thalassemia carriers.

\begin{tabular}{|c|c|c|c|c|c|}
\hline \multirow[t]{2}{*}{ Blood index } & \multicolumn{4}{|c|}{ Subjects } & \multirow[t]{2}{*}{$\mathrm{p}$} \\
\hline & $-\alpha^{3.7} / \alpha \alpha$ & $-\alpha^{3.7} /-\alpha^{3.7}$ & $\beta$-thalassemia & $\alpha \alpha / \alpha \alpha$ & \\
\hline $\mathrm{Hb}(\mathrm{g} / \mathrm{dL})^{*}$ & $12.5 \pm 1.79^{\mathrm{a}, \mathrm{b}}$ & $12.1 \pm 0.43^{\mathrm{a}}$ & $11.4 \pm 0.88^{\mathrm{a}}$ & $13.7 \pm 1.31^{\mathrm{b}}$ & $<0.05$ \\
\hline $\mathrm{RBC}\left(\times 10^{12} / \mathrm{L}\right)^{*}$ & $5.16 \pm 0.40^{\mathrm{a}}$ & $5.69 \pm 0.21^{\mathrm{a}, \mathrm{b}}$ & $5.64 \pm 0.50^{\mathrm{b}}$ & $5.01 \pm 0.49^{\mathrm{a}}$ & $<0.05$ \\
\hline $\operatorname{MCV}(\mathrm{fL})^{*}$ & $74.7 \pm 6.29^{\mathrm{a}}$ & $63.7 \pm 0.17^{\mathrm{a}, \mathrm{b}}$ & $64.6 \pm 4.07^{\mathrm{b}}$ & $83.1 \pm 4.86^{\mathrm{c}}$ & $<0.05$ \\
\hline RDW (\%) & $15.7 \pm 2.43^{\mathrm{a}, \mathrm{b}}$ & $17.1 \pm 0.49^{\mathrm{b}, \mathrm{c}}$ & $18.2 \pm 1.21^{\mathrm{c}}$ & $14.9 \pm 1.70^{\mathrm{a}}$ & $<0.05$ \\
\hline
\end{tabular}

Values are means \pm SD. Hb: hemoglobin; MCV: mean corpuscular volume; MCH: mean corpuscular hemoglobin; RBC: red blood cells; RDW: red cell distribution width. Values identified by the same letters do not differ significantly. Hb and RBC were compared with the SNK test, and MCV, MCH and RDW by the Mann-Whitney test to account for non-normality. *Analyses done using values corrected for age and sex.

genotypes: F:55.02; $\mathrm{p}<0.001)$. Univariate analysis of $\mathrm{Hb}$ revealed significant differences in $\mathrm{Hb}$ values between the group with normal genotypes and the other groups of genotypes and between the group with the $-\alpha^{3.7}$ deletion and the other groups of genotypes; there were also significant differences in the RBC values between individuals with $\beta$-thalassemia trait and the other groups, except for $-\alpha^{3.7} /-\alpha^{3.7}$ individuals. The Mann-Whitney test revealed significant differences for the MCV and $\mathrm{MCH}$ indices between individuals with normal genotypes and all the other groups, and between individuals with $\beta$-thalassemia trait and the $-\alpha^{3.7} / \alpha \alpha$ genotype.

\section{Discussion}

With the exception of a previous investigation based on a small sample from the Afro-Uruguayan population (Da Luz et al., 2006), this is the first study to examine the frequency of hemoglobinopathies in Uruguay, despite the fact that the population of this country originated from pop- ulations in which hemoglobinopathies are an important health problem.

Although the allelic frequency observed for the $\beta^{\mathrm{S}}$ mutation $(0.38 \%)$ cannot be extrapolated to the Uruguayan population as a whole because the samples consisted mostly of individuals from the city of Montevideo who attended CHPR (a public hospital), it was nevertheless similar to that estimated for the Uruguayan population $(0.3 \%)$ using the carrier and allelic frequencies previously reported for $\mathrm{HbS}(10 \%$ and $5 \%$, respectively) in Afro-Uruguayans (Da Luz et al., 2006). The overall frequency of $\mathrm{HbS}$ carriers in the sample was slightly lower than that observed in southern Brazil, a region that shares borders with Uruguay and where a carrier frequency of $1.2 \%$ has been reported for newborns (Daudt et al., 2002). In contrast, there was a greater difference between the frequency in the Uruguayan population in the present study and that in populations from northeastern Brazil, where there is a greater contribution from African populations and the frequency of $\mathrm{HbS}$ carriers 
ranges from 5.1\% to 11.4\% (Azevedo et al., 1980; Bandeira et al., 1999; Adorno et al., 2005).

The frequency of the $\beta^{\mathrm{S}}$ mutation in the sample of African origin in the present study $(1.1 \%)$ was lower than previously observed (5\%) (Da Luz et al., 2006); Table 1 shows that the genotypic frequencies differed significantly between the two studies. This difference can be explained by the greater African contribution in the latter study in which the population came mainly from Afro-Uruguayan social organizations and was selected based on ancestry and phenotypic traits, whereas in the present study the existence of one Afro-descendant grandparent was sufficient for an individual to be classified as Afro-Uruguayan.

The presence of Bantu and Benin haplotypes (frequencies not given here because of the small number of cases) also agreed with data from the previous study in Uruguay that showed a predominance of the Bantu haplotype. These findings are compatible with historical and demographic data on the origin of African slaves that indicate a major contribution by individuals from Bantu-speaking groups (Isola, 1975). The predominance of the Bantu haplotype has also been observed in many other countries and regions of South America (Muniz et al., 1995; Pante de Sousa, 1999; Moreno et al., 2002). In the Americas, the Benin haplotype is most frequent in the north of South America, the Caribbean region and North America (Antonarakis et al., 1984; Arends et al., 2000; Vivenes de Lugo et al., 2003; Galiza Neto et al., 2004; Adorno et al., 2005) whereas the Senegal haplotype is found in high frequencies in isolated Amazonian Afro-Brazilian communities (Pante de Sousa et al., 1999).

Interestingly, only one carrier of $\beta$-thalassemia was detected. This child had the $\beta^{0}$ codon $39(\mathrm{C}>\mathrm{T})$ mutation, the most frequent $\beta$-thalassemia mutation found in neighboring Brazil and Argentina (Martins et al., 1993; Roldan et al., 1997; Rossetti et al., 2004). As expected, because this individual belonged to the sample without African ancestry, the frequency of $\beta$-thalassemia alleles in this group $(0.41 \%)$ was similar to the global frequency observed in Spain $(0.41 \%)$ and in some regions of northern Italy $(0.5 \%)$, a part of the country where the lowest frequencies of $\beta$-thalassemia are found (Villegas et al., 1992, 2001; Weatherall and Clegg, 2001; Calvo-Villas et al., 2006).

The $\alpha^{-3.7}$ thalassemia carrier frequency ( $3 \%$ ) in the total CHPR sample was similar to that found in Spaniards (4.4\%), Portuguese (3.5\%) and Italians (4.1\%) (Fei et al., 1989; Villegas et al., 1992; Peres et al., 1995; Weatherall and Clegg, 2001). When we analyzed the sub-sample with African ancestry, the $\alpha^{-3.7}$ mutation carrier frequency increased and was $6.5 \%$ higher than that for the whole sample but, as expected from the admixture, was lower than that observed in parental African populations, where the frequency of $\alpha$-thalassemia carriers ranges from $11 \%$ to $50 \%$ (Weatherall and Clegg, 2001). The $\alpha^{-3.7}$ mutation carrier frequency in the sub-sample with African ancestry was also lower than that observed in Afro-Brazilian populations, where the carrier frequency ranges from $7 \%$ to $21 \%$ (Sonati et al., 2001; Adorno et al., 2005; Souza et al., 2009; Wagner et al., 2010), possibly because of a higher non-African admixture in this Afro-Uruguayan population. The $\alpha$-thalassemia frequencies for Afro-descendants with microcytosis $(33.3 \%)$ and the group of children with microcytosis and hypochromia (32.3\%) were both similar to the frequency observed in a similar sample from the southern Brazilian state of Rio Grande do Sul (31.7\%) (Wagner et al., 2010) and lower than that observed for a population in southeastern Brazil in which $\alpha$-thalassemia explained about $50 \%$ of the cases of microcytosis (Borges et al., 2001).

The sample of 31 patients admitted to the PHOS exhibited the $-(\alpha)^{20.5}$ deletion, a mutation related to European or Asian ancestry (Huisman et al., 1996; Hardison et al., 1998). The presence of this deletion in a homozygous state or associated with other $\alpha$-thalassemia mutations produces hydrops fetalis or $\mathrm{HbH}$ disease, a severe hemoglobinopathy not described to date in Uruguay.

In conclusion, the data presented here are the first on the frequency of hemoglobinopathies in a relatively large Uruguayan sample and show that these diseases have nonnegligible frequencies. Although the sample analyzed was not fully representative of the Uruguayan population, about a sixth of the births in this country occur in the CHPR. The frequencies of hemoglobinopathies in this study underline the need for strategies to prevent further health complications. In light of this, Afro-Uruguayan associations have been pressing for hemoglobinopathies to be included in the universal screening of neonates (see Queiruga et al., 2010, for screening data). Furthermore, data on RBC parameters in individuals with normal and thalassemia genotypes can help to detect $\alpha$-thalassemia in patients suspected of having the disease. Our findings encourage us to investigate the distribution of hemoglobinopathies in a more comprehensive sample with greater African and/or European genetic contributions and to evaluate the benefits of including tests to detect hemoglobinopathies in the universal screening of neonates in Uruguay.

\section{Acknowledgments}

This work was supported by the Comisión Sectorial de Investigación Científica (CSIC, UdelaR, Uruguay) and Fundação de Amparo à Pesquisa do Estado de São Paulo (FAPESP, grant no. 2008/57441-0), Brazil.

\section{References}

Adorno EV, Couto F, Moura Neto JP, Menezes JF, Rego Dos Reis MG and Goncalves MS (2005) Hemoglobinopathies in newborns from Salvador, Bahia, Northeast Brazil. Cad Saúde Pública 21:292-298. 
Allison AC (1956) The sickle cell and hemoglobin C genes in some populations. Ann Hum Genet 21:67-89.

Antonarakis SE, Boehm CD, Serjeant GR, Theisen CE, Dover GJ and Kazazian Jr HH (1984) Origin of the $\beta S$-globin gene in blacks: The contribution of recurrent mutation or gene conversion or both. Proc Natl Acad Sci USA 81:853-856.

Azevêdo ES, Alves AFP, Silva MCBO, Souza MGF, Lima AMVMD and Azevêdo WC (1980) Distribution of abnormal hemoglobins and glucose-6-phosphate dehydrogenase variants in 1200 school children of Bahia, Brazil. Am J Phys Anthropol 53:509-512.

Bandeira FMGC, Leal MC, Souza RR, Furtado VC, Gomes YM and Marques NM (1999) Características de recém-nascidos portadores de hemoglobina "S" detectados através de triagem em sangue de cordão umbilical. J Pediatr (Rio Janeiro) 75:167-171.

Borges E, Wenning E, Kimura EM, Gervasio SA, Costa FF and Sonati MF (2001) High prevalence of alpha-thalassemia among individuals with microcytosis and hypochromia without anemia. Braz J Med Biol Res 34:759-762.

Calvo-Villas JM, Zapata MF, Cuesta J, De La Iglesia S, Ropero P, Carreter E and Sicilia F (2006) Prevalencia de hemoglobinopatías en mujeres gestantes en el área sanitaria de Lanzarote. An Med Interna 23:206-212.

Castro de Guerra D, Hutz M, Bortolini MC and Salzano FM (1997) Beta-globin gene cluster haplotypes in an admixed Venezuelan population. Am J Hum Biol 9:323-327.

Da Luz J, Sans M, Kimura EM, Martins D, Sonati MF and Costa FF (2006) Alpha-thalassemia, HbS, and beta-globin gene cluster haplotypes in two Afro-Uruguayan sub-populations from northern and southern Uruguay. Genet Mol Biol 29:595-600.

Daudt LE, Zechmaister D, Portal L, Camargo Neto E, Silla LMR and Giugliani R (2002) Triagem neonatal para hemoglobinopatias: Um estudo piloto em Porto Alegre, Rio Grande do Sul, Brasil. Cad Saúde Pública 18:833-841.

Fei YJ, Kutlar H, Harris H, Wilson MM, Milana A, Sciacca P, Schiliro G, Masala B, Manca L and Altav C (1989) A search for anomalies in the zeta, alpha, beta, and gamma globin gene arrangements in normal black, Italian, Turkish, and Spanish newborns. Hemoglobin 13:45-65.

Foglietta E, Deidda G, Graziani B, Modiano G and Bianco I (1996) Detection of $\alpha$-globin gene disorders by a simple PCR methodology. Haematologica 81:387-396.

Galiza Neto GC, Pitombeira MS, Vieira HF, Vieira ML and Chaves FDAB (2005) Analysis of $\beta^{S}$ globin haplotypes in Ceará, Brazil. J Bras Patol Med Lab 41:315-321.

Guerreiro JF, Figuereido S, Santos SE and Zago MA (1992) Beta-globin gene cluster haplotypes in Yanomama Indians from the Amazon region of Brazil. Hum Genet 89:629-631.

Hall GW, Thein S, Newland A, Chisholm M, Traeger-Synodinos J, Kanavakis E, Kattamis C and Higgs DR (1993) A base substitution $(\mathrm{T} \rightarrow \mathrm{C})$ in codon 29 of the alpha 2-globin gene causes alpha thalassemia. Br J Haematol 85:546-552.

Hardison R, Chui D, Riemer C, Miller W, Carver M, Molchanova T, Efremov G and Huisman THJ (1998) Access to "A Syllabus of Human Hemoglobin Variants (1996)" via the World Wide Web. Hemoglobin 22:113-127.

Higgs DR, Vickers MA, Wilkie AOM, Pretorius IM, Jarman AP and Weatherall DJ (1989) A review of the molecular genetics of the human $\alpha$-globin cluster. Blood 73:1081-1104.
Isola E (1975) La esclavitud en el Uruguay desde sus comienzos hasta su extinción (1743-1852). Comision Nacional de Homenaje del Sesquicentenario de Los Hechos Históricos de 1825 (eds) Talleres Gráficos Monteverde y Cía, Montevideo, pp 54-94.

Kattamis AC, Camaschella C, Sivera P, Surrey S and Fortina P (1996) Human $\alpha$-thalassemia syndromes: Detection of molecular defects. Am J Hematol 53:81-91.

Kulozik AE, Wainscoat G, Serjeant GR, Kar BC, Al-Awamy B, Essan GJF, Falusi AG, Haque SQ, Hilali AM, Kate S, et al. (1986) Geographical survey of beta S-globin gene haplotypes: Evidence for an independent Asian origin of the sickle-cell mutation. Am J Hum Genet 39:239-244.

Long JC, Chakravarti C, Bohem C, Antonarakis S and Kazazian $\mathrm{HH}$ (1990) Phylogeny of human beta-globin haplotypes and its implications for recent human evolution. Am J Phys Anthropol 81:113-130.

Martins CS, Ramalho A, Sonati MF, Goncalvez MS and Costa FF (1993) Molecular characterisation of beta thalassemia heterozygotes in Brazil. J Med Genet 30:797-798.

Masmas TN, Garly ML, Lisse IM, Rodrigues A, Petersen PT and Birgen H (2006) Inherited hemoglobin disorders in GuineaBissau, West Africa: A population study. Hemoglobin 30:355-364.

Migot-Nabias F, Pelleau S, Watier L, Guitard J, Toly C, De Araujo C, Ngom MI, Chevillard C, Gaye O and Garcia A (2006) Red blood cell polymorphisms in relation to Plasmodium falciparum asymptomatic parasite densities and morbidity in Senegal. Microbes Infect 8:2352-2358.

Miller SA, Dykes DD and Polesky HF (1988) A simple salting out procedure for extracting DNA from human nucleated cell. Nucleic Acid Res 16:1215-1216.

Miranda SRP, Fonseca SF, Figuereido MS, Yamamoto M, Grotto HZW, Saad STO and Costa FF (1997) Hb Köln [ $\alpha 2 \beta 298(\mathrm{FG} 5)$ Val-Met] identified by DNA analysis in a Brazilian family. Braz J Genet 20:745-748.

Moreno N, Martínez JA, Blanco Z, Osorio L and Hackshaw (2002) Beta-globin gene cluster haplotypes in Venezuelan sickle cell patients from the State of Aragua. Genet Mol Biol 25:21-24.

Pante de Sousa G, Mousinho-Ribeiro RC, Melo dos Santos EJ and Guerreiro JF (1999) $\beta$-globin haplotypes analysis in AfroBrazilians from three Amazon regions: Evidence for a signature gene flow from Atlantic West Africa. Ann Hum Biol 26:365-373.

Peres MJ, Romão L, Carreiro H, Picanço I, Batalha L, Magalhães HA, Martins MC and Lavinha J (1995) Molecular basis of alpha-thalassemia in Portugal. Hemoglobin 19:343-352.

Ramalho AS, Jorge RN, Oliveira JA and Pedreira DA (1976) Hemoglobina $\mathrm{S}$ em recém-nascidos brasileiros. J Pediatr 41:9-10.

Roldán A, Gutierrez M, Cygler A, Bonduel M, Sciuccati G and Torres AF (1997) Molecular characterization of beta-thalassemia genes in an Argentine population. Am J Hematol 54:179-182.

Rossetti L, Targovnik H and Varela V (2004) The molecular basis of beta-thalassemia in Argentina. Influence of the pattern of immigration from the Mediterranean Basin. Haematologica 88:746-747. 
Sans M, Salzano FM and Chakraborty R (1997) Historical genetics in Uruguay: Estimates of biological origins and their problems. Hum Biol 69:161-170.

Souza AE, Cardoso GL, Takanashi SY and Guerreiro JF (2009) Alpha-thalassemia (3.7 kb deletion) in a population from the Brazilian Amazon region: Santarém, Pará State. Genet Mol Res 8:477-481.

Steinberg MH, Forget BG, Higgs DR and Nagel RL (2001) Disorders of Hemoglobin: Genetics, Pathophysiology, and Clinical Management. Cambridge University Press, Cambridge, $1268 \mathrm{pp}$.

Sutton M, Bouhassira EE and Nagel RL (1989) Polymerase chain reaction amplification applied to the determination of betalike globin gene cluster haplotypes. Am J Hematol 32:6669 .

Tan AS, Quah T, Low P and Chong SS (2001) A rapid and reliable 7-deletion multiplex polymerase chain reaction assay for alpha-thalassemia. Blood 98:250-251.

Villegas A, Sanchez J and Sal Del Rio E (1992) Alpha-globin genotypes in a Spanish population. Hemoglobin 16:427-429.

Villegas A, Ropero P, González F, Anguita E and Espinós E (2001) The thalassemia syndromes: Molecular characterization in the Spanish population. Hemoglobin 25:273-283.

Vívenes De Lugo M, Rodríguez-Larralde A and Castro de Guerra D (2003) Beta-globin gene cluster haplotypes as evidence of African gene flow to the northeastern coast of Venezuela. Am J Hum Biol 15:29-37.

Wagner SC, de Castro SM, Gonzalez TP, Santin AP, Filippon L, Zaleski CF, Azevedo LA, Amorin B, Callegari-Jacques SM and Hutz M (2010) Prevalence of common $\alpha$-thalassemia determinants in south Brazil: Importance for the diagnosis of microcytic anemia. Genet Mol Biol 33:641-645.

Weatherall D (2004) The thalassemias: The role of molecular genetics in an evolving global health problem. Am J Hum Genet 74:385-392.
Weatherall DJ and Clegg JB (2001) Inherited haemoglobin disorders: An increasing global health problem. Bull World Health Organ 79:704-712.

WHO (2008) Worldwide prevalence of anaemia 1993-2005. In: de Benoist B, McLean E, Egli I and Cogswell M (eds) WHO Global Database on Anaemia. World Health Organization, $24 \mathrm{pp}$.

\section{Internet Resources}

Bucheli M and Cabella W (2006) Perfil demográfico y socioeconómico de la población uruguaya según su ascendencia racial. Informe Temático, Encuesta Nacional de Hogares Ampliada 2006. Instituto Nacional de Estadística, http://www.ine.gub.uy/enha2006/Informe\%20final\%20raz a.pdf.

Huisman THJ, Carver MF and Efremov GD (1996) A Syllabus of Human Hemoglobin Variants. The Sickle Cell Anemia Foundation. Augusta, USA, http://globin.cse.psu.edu/html/.../variants/.

I.N.E. (1997) Encuesta continua de hogares. Módulo de raza. http://www.ine.gub.uy/biblioteca/raza/MODULO_RAZA. pdf.

Queiruga G, Lemes A, Ferola C, Machado M, Quejo C, Garlo P and Parallada G (2010) Pesquisa neonatal: Lo que puede prevenir una gota de sangre. Jornada Actualidad y Nuevas Metas en la Implementación del Sistema Nacional de Pesquisa Neonatal, Centro de Estudios en Seguridad Social, Salud y Administración, Montevideo, http://portal.campusvirtualsp.org/virtualcampus/uruguay/drupal/index.php?q=node/17.

Schneider S, Roessli D and Excoffier L (2000) Arlequin: A software for population genetics data analysis. User manual version 2.000. http://cmpg.unibe.ch/software/arlequin3/arlequin31.pdf.

Associate Editor: Mara H. Hutz

License information: This is an open-access article distributed under the terms of the Creative Commons Attribution License, which permits unrestricted use, distribution, and reproduction in any medium, provided the original work is properly cited. 